\title{
Phosphorus and faecal bacteria in runoff from horse paddocks and their mitigation by the addition of P-sorbing materials
}

\author{
Jaana Uusi-Kämppä, Aaro Närvänen, Janne Kaseva and Håkan Jansson \\ MTT Agrifood Research Finland, Plant Production Research, Planta, Fl-31600 Jokioinen, Finland \\ e-mail: jaana.uusi-kamppa@mtt.fi
}

\begin{abstract}
The growing popularity of horse keeping is accompanied by an increase of phosphorus (P) and faecal micro-organisms from outdoor paddocks. We used an indoor rainfall simulation to monitor concentrations of dissolved reactive $P$ (DRP) and faecal coliforms in runoff and percolation water from different paddock footings. Drainage water was also monitored from two paddocks constructed of woodchips. Sand retained more DRP $(p<0.0001)$ and coliforms from percolation water than woodchips. Some of the footings were amended with P-sorbing materials, such as [ $\left.\mathrm{Ca}(\mathrm{OH})_{2}\right],\left[\mathrm{Fe}_{2}\left(\mathrm{SO}_{4}\right)_{3}\right]$, or Fe-gypsum, to retain DRP. High DRP concentrations $\left(17-18 \mathrm{mg} \mathrm{l}^{-1}\right)$ were observed in runoff from a woodchip footing amended earlier with $\mathrm{Ca}(\mathrm{OH})_{2}$ and in sand footing amended with $\mathrm{CaCO}_{3}$. However, application of Fe-gypsum to woodchips decreased the DRP load in percolation water by $83 \%$ compared to the footing without Fe-gypsum. Fe compounds were better than Ca compounds. The decrease in coliforms was usually small due to the modest $\mathrm{pH}$ changes in the water.
\end{abstract}

Key words: equine area, faecal indicator bacteria, footing materials, runoff, water quality

\section{Introduction}

Despite the growth of the horse industry, with new stables being established even near population centres, few studies have focused on the effects of horse paddocks on water quality (Airaksinen et al. 2007, Sullivan 2010). Among the total 75500 horses in Finland, roughly 13000 are kept around the cities of Helsinki (Uusimaa) and Turku (Southwest Finland) (Suomen Hippos Oy et al. 2012). Sand, topsoil (often clay), or woodchips are commonly used as footing materials, with the percolation capacity of water being generally highest for woodchips and lowest for clay. The paddock conditions also affect horse welfare. Poorly managed paddocks or mud and manure can soften the hoof, facilitating microbe invasion (Stephenson et al. 2003).

In Finland and Sweden, horses are usually kept in small, fenced-off areas near the stables (Pikkarainen 2005, Parvage et al. 2011). According to Pikkarainen (2005), two horses are kept together for an average of 7 hours daily in a paddock with an average size of $1100 \mathrm{~m}^{2}$ (year around horse density of $5.3 \mathrm{ha}^{-1}$ ). Finland is estimated to have up to 35000 paddocks with a total area of 3800 ha. One horse produces $10 \mathrm{~kg}$ of phosphorus (P) and $61 \mathrm{~kg}$ of nitrogen (N) annually in dung and urine (Jouni Nousiainen, personal communication, MTT Jokioinen, 19 April 2011). If the horse density is $5.3 \mathrm{ha}^{-1}$, the annual input of $\mathrm{P}$ and $\mathrm{N}$ may be more than 50 and $300 \mathrm{~kg} \mathrm{ha}^{-1}$, respectively, to the paddock area with little or no vegetation. In comparison, the maximum annual amounts of fertilizer $\mathrm{P}$ and $\mathrm{N}$ allowed in Finland for grassed fields are 70 and $250 \mathrm{~kg} \mathrm{ha}^{-1}$, respectively.

In Finland and Sweden, high concentrations of dissolved reactive P (DRP, 1.0 to $15 \mathrm{mg} \mathrm{l}^{-1}$ ) and total P (TP, 1.5 to $18.8 \mathrm{mg}^{-1}$ ) have been measured in the drainage and surface runoff from horse paddocks (Airaksinen et al. 2007, Närvänen et al. 2008, Parvage et al. 2011). Moderate and high concentrations (5.5 to $70.8 \mathrm{mg} \mathrm{l}^{-1}$ ) of acid ammonium acetate extractable $P\left(P_{A c}\right)$ have also been observed in the soil floors of paddocks (Airaksinen et al. 2007, Närvänen et al. 2008). In many studies, the DRP concentrations in surface runoff have increased linearly with the soil test values for $P$ in the surface soil layer (Sharpley et al. 1977, Jansson et al. 2000, Närvänen et al. 2008). Thus, horse paddocks probably cause local nutrient and microbe loss to watercourses, resulting in water eutrophication, algae blooming (Correll 1998), and hygiene problems (Sinton et al. 1998).

In earlier studies, artificial wetlands and the addition of P-sorbing materials to runoff water were tested as methods for purifying paddock runoff (Närvänen et al. 2008, Kynkääniemi et al. 2010). In a study by Närvänen et al. (2008), the DRP and TP in the runoff was reduced $95 \%$ and $81 \%$, respectively, after the addition of $160 \mathrm{~kg}$ ferric sulphate per year into the runoff water from a 0.5 ha paddock with seven young stallions. We studied the addition of $\mathrm{Ca}$ or Fe-containing amendments, such as $\mathrm{Fe}_{2}\left(\mathrm{SO}_{4}\right)_{3}, \mathrm{Ca}(\mathrm{OH})_{2}$, or Fe-gypsum, to the surface layer of paddock footings 
because several studies had shown the potential of P-sorbing materials to reduce the solubility of $\mathrm{P}$ in soils (Agyin-Birikorang et al. 2007) and DRP losses in field runoff (Penn and Bryant 2006). Different kinds of materials have been studied for their P retention properties (O'Connor et al. 2005), but those containing Ca, Al, or Fe in soluble or solid oxide forms have been the most promising.

The purpose of this paper is 1 ) to discuss $P$ losses and the numbers of coliform bacteria in runoff from horse paddocks, 2) to demonstrate how different paddock footing materials (sand, clay soil, woodchips, and crushed stone) affect $\mathrm{P}$ concentrations in paddock runoff, and 3 ) to estimate the potential of different amounts of P-sorbing materials in footings to reduce the transport of DRP, TP, and faecal coliforms in runoff and percolation water. Whether sand, due to its smaller pore size, is better at removing DRP and coliforms compared to woodchips was evaluated, as well as whether runoff and percolation waters are acid or alkaline enough to remove coliforms after the addition of $\mathrm{Fe}_{2}\left(\mathrm{SO}_{4}\right)_{3}$ or $\mathrm{Ca}(\mathrm{OH})_{2}$.

\section{Material and methods}

Field monitoring of the mitigation of $\mathrm{P}$ in drainage water was performed by adding $\mathrm{P}$-sorbing compounds containing Fe or Ca to the woodchips used as a footing material in horse paddocks. Grab samples of drainage flow were collected from the paddocks for laboratory analyses (Fig. 1). A rainfall simulation technique (Uusitalo and Aura 2005) was utilized to investigate P loss and the hygienic quality of runoff and percolation water from different footing materials in rainfall study 1 and 2, respectively (Fig. 1). Samples from paddock footings or footings constructed with sand or woodchips were amended with materials containing Fe or Ca. The samples were placed under a rainfall simulator, and the runoff or percolation water was collected for laboratory analysis. Coliform bacteria (faecal coliforms, Escherichia coli), faecal streptococcus, and sulfite-reducing clostridia were used as indicators of water quality to determine the presence of pathogens.

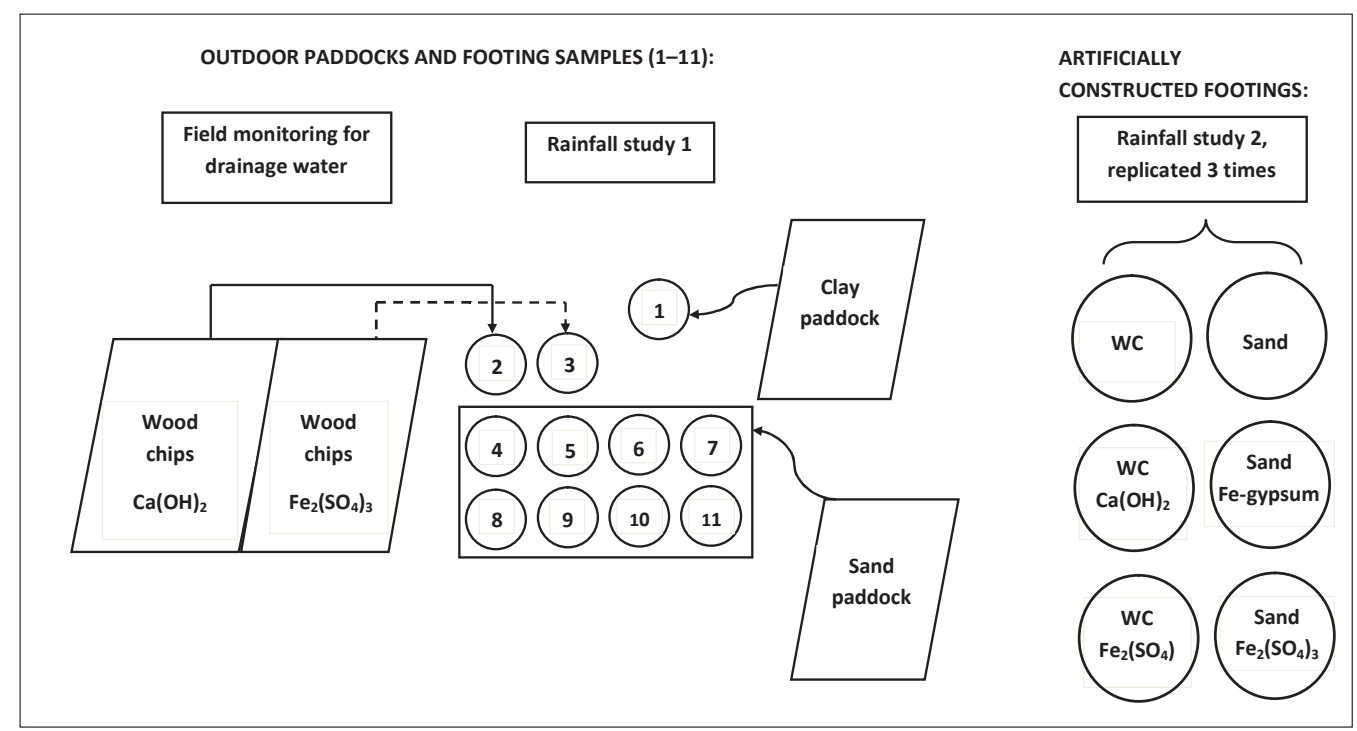

Fig.1. Paddock footings in the three experiments.

\section{Field monitoring of drainage water}

The addition of P-sorbing materials to reduce nutrient concentrations in the drainage water from two paddocks (17 Icelandic horses ha ${ }^{-1}$ ) was studied in south-western Finland in 2005-2008 (Table 1). Slaked lime [Ca(OH), 0.84 tn ha $\left.{ }^{-1}\right]$ or granulated ferric sulphate $\left[\mathrm{Fe}_{2}\left(\mathrm{SO}_{4}\right)_{3}\right.$, trade name Ferrix-3, $\left.0.84 \mathrm{tn} \mathrm{ha-1}\right]$ was added to the surface layer of two paddocks (1900 $\mathrm{m}^{2}$ each) covered with a 20-cm layer of woodchips only, or with a 15-cm layer of sand and a 10 -cm layer of woodchips (Fig. 2). Slaked lime was added to the middle layer of woodchips, whereas ferric sulphate was added to the surface of the woodchip layer. The paddocks were established on clay soil. A total of 12 grab samples were taken from the drainage flow two to four times per year for water analysis. Sampling was performed on a day with high rainfall $(>10 \mathrm{~mm}$ ) or one of the subsequent days. 
Table 1. Characteristics of footing materials and amendments, their application rates, and the amounts of $\mathrm{Ca}$ and Fe added.

\begin{tabular}{|c|c|c|c|}
\hline $\begin{array}{l}\text { Footing material/ } \\
\text { Amendment }\end{array}$ & $\begin{array}{l}\text { Application } \\
\text { rate }\end{array}$ & $\begin{array}{c}\text { Ca } \\
\text { applied } \\
\text { tn ha-1 }\end{array}$ & $\begin{array}{c}\mathrm{Fe} \\
\text { applied }\end{array}$ \\
\hline \multicolumn{4}{|l|}{ Field monitoring (drainage water) } \\
\hline $\mathrm{Ca}(\mathrm{OH})_{2}$ (slaked lime) & 0.84 & 0.45 & 0 \\
\hline $\mathrm{Fe}_{2}\left(\mathrm{SO}_{4}\right)_{3}($ Ferix-3), Kemira Oyj & 0.84 & 0 & 0.16 \\
\hline \multicolumn{4}{|l|}{ Rainfall study 1 (surface runoff) } \\
\hline \multirow[t]{3}{*}{$\mathrm{Ca}(\mathrm{OH})_{2}$} & 2.7 & 1.5 & 0 \\
\hline & 5.4 & 2.9 & 0 \\
\hline & 10.7 & 5.8 & 0 \\
\hline \multirow[t]{3}{*}{$\mathrm{Fe}_{2}\left(\mathrm{SO}_{4}\right)_{3}(\mathrm{PIX}-115)+\mathrm{CaCO}_{3}$} & $2.0+6.7$ & 2.3 & 0.24 \\
\hline & $4.1+8.9$ & 3.6 & 0.48 \\
\hline & $6.2+13.3$ & 5.3 & 0.71 \\
\hline $\mathrm{CaCO}_{3}$ & 4.4 & 1.8 & 0 \\
\hline \multicolumn{4}{|l|}{ Rainfall study 2 (percolation water) } \\
\hline Aspen woodchips (moisture $26 \%$ ) & 830 & n.a. & n.a. \\
\hline Sand $^{(1)}$ (moisture $\left.4 \%\right)$ & 2100 & n.a. & n.a. \\
\hline Quartz sand $(0.5-1.6 \mathrm{~mm})$ & 830 & n.a. & n.a. \\
\hline $\mathrm{Ca}(\mathrm{OH})_{2}$ & 5.6 & 3.0 & 0 \\
\hline $\begin{array}{l}\text { Fe-gypsum }{ }^{(2)}\left(\mathrm{Fe}_{2} \mathrm{O}_{3} \sim 14 \%, \mathrm{CaSO}_{4} \times 2 \mathrm{H}_{2} \mathrm{O} \sim 70 \%,\right. \\
\left.\mathrm{CaCO}_{3} \sim 10 \%, \mathrm{TiO}_{2} \sim 5 \% \text {; moisture } 15 \%\right)\end{array}$ & 5.6 & 0.82 & 0.66 \\
\hline $\mathrm{Fe}_{2}\left(\mathrm{SO}_{4}\right)_{3}($ Ferix-3) & 1.1 & 0 & 0.22 \\
\hline
\end{tabular}

(1) Particle size distribution: 4.2\% (6-8 mm), 4.3 (4-6 mm), 7.9\% (2-4 mm), 15.9\% (1-2 mm) and $67.7 \%(<1 \mathrm{~mm})$

(2) Pori plant of Sachtleben Pigments Oy

n.a. not available

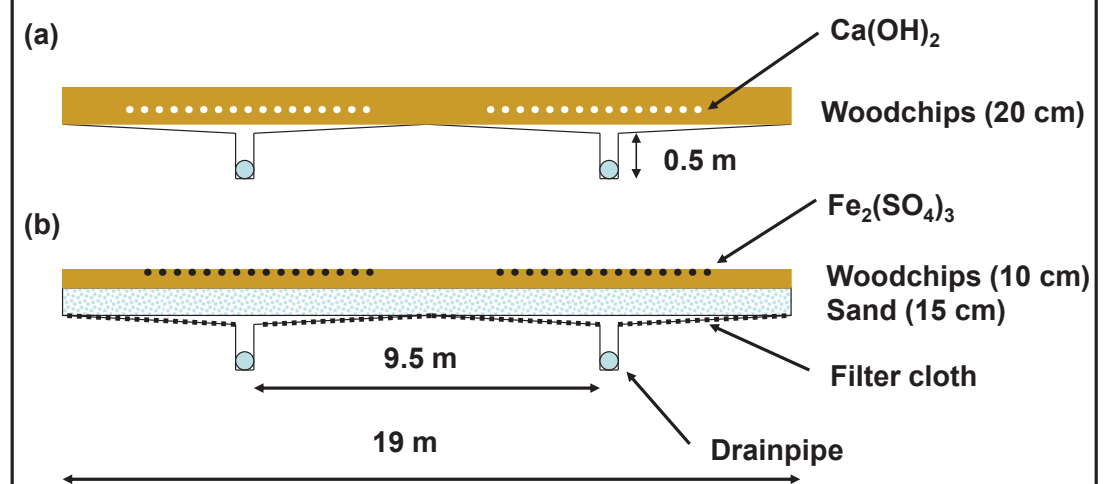

Fig. 2. Cross-sections of two paddocks constructed using woodchips and amended with (a) $\mathrm{Ca}(\mathrm{OH})_{2}$ (slaked lime) or (b) $\mathrm{Fe}_{2}\left(\mathrm{SO}_{4}\right)_{3}$ (Ferix-3) during the field monitoring study. 


\section{Rainfall study 1 and surface runoff}

In the first rainfall simulation (surface runoff study), samples of footing materials (sand, clay soil, and woodchips) were carefully taken by spade from four outdoor paddocks and put into metal bowls (diameter $24 \mathrm{~cm}$, height $6 \mathrm{~cm}$ ) in August 2006 (Fig. 1). Two of the paddocks were constructed out of woodchips and amended with slaked lime $[\mathrm{Ca}(\mathrm{OH}) 2]$ or ferric sulphate [Fe(SO4)3] as described above (Fig. 2). The bowls with samples were stored in plastic bags for a couple of days. Before the rainfall simulation, $2.7,5.4$, or 10.7 th ha- 1 of $\mathrm{Ca}(\mathrm{OH}) 2$ was added to the surface of sand samples to test the potential to decrease $P$ runoff, with one replicate serving as an untreated control (Table 1). Three other sand samples were treated with 2.0, 4.1, or 6.2 tn ha-1 of liquid ferric sulphate (Fe2(SO4)3 trade name PIX-115) while saturating the samples with water. Chalk powder (CaCO3) was added $(6.7,8.9$, or 13.3 tn ha-1) to the PIX-115-treated sand 30 min after starting the rainfall simulation. The results from the addition of $\mathrm{Fe} 2(\mathrm{SO} 4) 3$ and $\mathrm{CaCO} 3$ are from the water samples taken after the addition of $\mathrm{CaCO}$. Nothing was added to the clay footing samples. The paddock management is presented in Table 2.

Before the rainfall simulation, the footing samples were fully saturated with 700 to $1400 \mathrm{ml}$ of deionised water and set at a $4 \%$ incline under a stationary drip-type rainfall simulator. The samples were kept in rain (deionised water; $\left.21 \mathrm{~mm} \mathrm{~h}^{-1}\right)$ for $90 \mathrm{~min}$ and three bottles (500 ml each) of surface runoff water collected for analysis. The measured P concentrations were corrected for dilution during the rainfall simulation, similar to the study by Uusi-Kämppä et al. (2012). The hygiene indicators, however, were not corrected due to the logarithmic growth of micro-organisms.

\begin{tabular}{|c|c|c|c|}
\hline No. & Footing materials & $\begin{array}{l}\text { Size } \\
\mathrm{m}^{2}\end{array}$ & $\begin{array}{l}\text { Horses } \\
\mathrm{ha}^{-1}\end{array}$ \\
\hline 1 & Clay & 800 & 20 \\
\hline 2 & Woodchips (WC) +0.84 tn ha- ${ }^{-1} \mathrm{Ca}(\mathrm{OH})_{2}$ & 1900 & 17 \\
\hline 3 & Woodchips (WC) +0.84 tn ha-1 $\mathrm{Fe}_{2}\left(\mathrm{SO}_{4}\right)_{3}($ Ferix-3) & 1900 & 17 \\
\hline 4 & Sand (control) & 520 & 20 \\
\hline 5 & Sand +2.7 tn ha $^{-1} \mathrm{Ca}(\mathrm{OH})_{2}$ & 520 & 20 \\
\hline 6 & Sand +5.3 tn ha $^{-1} \mathrm{Ca}(\mathrm{OH})_{2}$ & 520 & 20 \\
\hline 7 & Sand +10.7 tn ha $^{-1} \mathrm{Ca}(\mathrm{OH})_{2}$ & 520 & 20 \\
\hline 8 & Sand +2.0 tn ha-1 $\mathrm{Fe}_{2}\left(\mathrm{SO}_{4}\right)_{3}(\mathrm{PIX}-115)+6.7 \mathrm{tn} \mathrm{ha}^{-1} \mathrm{CaCO}_{3}$ & 520 & 20 \\
\hline 9 & Sand +4.1 tn ha-1 $\mathrm{Fe}_{2}\left(\mathrm{SO}_{4}\right)_{3}(\mathrm{PIX}-115)+8.9$ tn ha $^{-1} \mathrm{CaCO}_{3}$ & 520 & 20 \\
\hline 10 & Sand +6.2 tn ha- $\mathrm{Fe}_{2}\left(\mathrm{SO}_{4}\right)_{3}(\mathrm{PIX}-115)+13.3 \mathrm{tn} \mathrm{ha}^{-1} \mathrm{CaCO}_{3}$ & 520 & 20 \\
\hline 11 & Sand +4.4 tn ha ${ }^{-1} \mathrm{CaCO}_{3}$ & 520 & 20 \\
\hline
\end{tabular}

\section{Rainfall study 2 and percolation water}

Paddock footings ( 6 treatments $\times 3$ replicates) were artificially constructed in PVC cylinders (diameter $15 \mathrm{~cm}$, height $25 \mathrm{~cm}$ ) with a tight net at the bottom to allow water flow for percolation water analysis. A 15-cm layer of footing material, such as sand (particle size 0-8 mm) originating from a local gravel pit or aspen woodchips (10-20 mm), was added to a 5-cm layer of quartz sand (particle size 3-5 $\mathrm{mm}$ ) in the cylinders. Dried and powdered Fe-rich gypsum residue $\left(5.6 \mathrm{tn} \mathrm{ha}{ }^{-1}\right)$ from $\mathrm{TiO}_{2}$ production, powdered $\mathrm{Ca}(\mathrm{OH})_{2}\left(5.6 \mathrm{tn} \mathrm{ha}{ }^{-1}\right)$, or granulated ferric sulphate $\left[\mathrm{Fe}_{2}\left(\mathrm{SO}_{4}\right)_{3}\right.$, trade name Ferix-3, $1.1 \mathrm{tn} \mathrm{ha}^{-1}$ ] was applied to the surface layer to reduce $\mathrm{P}$ loss in percolation water (Table 1). More details about the materials and their chemical properties were presented by Uusi-Kämppä et al. (2012).

The PVC cylinders were placed on a collar (volume $240 \mathrm{ml}$, height $12 \mathrm{~mm}$ ) filled with quartz sand (diameter 3-5 $\mathrm{mm}$ ) and saturated from the bottom upwards with deionised water. The next day, the water was allowed to flow out for one hour to the bottom level of the sample and the percolation water collected for chemical and hygienic analyses (0-sample). Finally, 9.9 or $8.3 \mathrm{~g}$ (dry matter) of horse dung (TP concentration 1.75 and $1.55 \mathrm{mg} \mathrm{g}^{-1}$ ) was spread on the surface of the footing material, equal to 10 or $7 \mathrm{~kg} \mathrm{ha}^{-1}$ of TP, corresponding to the annual input of TP into a paddock area with a horse density of 1 horse ha ${ }^{-1}$. The results for hygienic indicators in dung are presented in Table 3.

The cylinders were placed under the rainfall simulator and percolation water collected for analysis. The duration 
of the rain event $\left(10 \mathrm{~mm} \mathrm{~h}^{-1}\right)$ was $6 \mathrm{~h}$ and $5 \mathrm{~h}$ on the first and second simulation day, respectively. The volume and mass of the percolation water were recorded. On the first day, approximately $1200 \mathrm{ml}$ of percolation water was obtained as six separate $200 \mathrm{ml}$ subsamples. The first three water samples were for chemical analysis, and the last three samples were pooled and then divided for chemical and hygienic analyses. The next day, $1000 \mathrm{ml}$ of percolation water was collected for chemical analysis. During the rainfall simulation, the temperatures of the laboratory air and deionised water were $20-21^{\circ} \mathrm{C}$ and $15.4{ }^{\circ} \mathrm{C}$, respectively. In all studies, the concentrations of DRP and TP and the levels of faecal bacteria in the deionised water used in the rainfall simulations were below the detection limit of the methods used.

\section{Water analysis}

For DRP analysis, water samples were filtered $(0.2 \mu \mathrm{m}$, Whatman, Maidstone, UK) on the day of collection. For TP analysis, unfiltered subsamples were digested with peroxide sulfate in an autoclave (Turtola 1996). Concentrations of DRP and TP were measured using a FIAstar autoanalyzer according to Finnish standards SFS 3025 (1986) and SFS 3026 (1986), respectively, which are based on the molybdate blue method and use of ascorbic acid as the reducing agent (Murphy and Riley 1962). The concentration of particulate P (PP) was estimated by calculating the difference between TP and DRP.

Water quality indicators were enumerated by a membrane filtration method. Water samples were filtered through a Millipore filter (diameter $47 \mathrm{~mm}$ ) with a pore size of $0.45 \mu \mathrm{m}$ (for sulfite-reducing clostridia $0.22 \mu \mathrm{m}$ ). Faecal coliforms and $E$. coli/coliforms were cultivated on $\mathrm{mFC}$ agar (Difco) (SFS 4088 1988) and Harlequin E. coli/coliform medium (LabM), respectively. The plates were incubated for $24 \mathrm{~h}$ at $44.5^{\circ} \mathrm{C}\left(\mathrm{mFC}\right.$ ) and $37^{\circ} \mathrm{C}$ (Harlequin) before enumeration. On the Harlequin medium, blue-green colonies were counted as presumptive $E$. coli, and all rosepink colonies were counted as presumptive coliforms (LabM). Faecal streptococcus and sulfite-reducing clostridia were incubated on KF-streptococcus medium (44 h, $44.5^{\circ} \mathrm{C}$ ) (SFS 3014 1984) or the Oxoid Anaerobic Jar (44 h, 37 $\left.{ }^{\circ} \mathrm{C}\right)$ (SFS-EN 26461-2 1993), respectively. Bacteria counts were expressed as the geometric means of the colony forming units (cfu) per $100 \mathrm{ml}$ of water.

\section{Statistical analysis}

In the field monitoring of drainage water and rainfall study 1 of surface runoff, statistical analysis was not possible due to the small number of samples. In rainfall study 2 of percolation water, the statistical analysis was based on the experimental design, a balanced incomplete block design comprising six treatments $(n=3)$ and five blocks. The date of the rainfall was the block factor. Four treatments were included in every block, except the last block, which had only two. All of the treatments could not be placed under the same rainfall, which is the reason why the incomplete block design was used.

Every treatment had a few observations in every block. In the analysis, these observations were summarized and the weighted means calculated from the concentrations. The model on which the analysis was based is as follows:

$\mathrm{y}_{\mathrm{ij}}=\mu+$ block $_{\mathrm{i}}+$ tre $_{\mathrm{j}}+\varepsilon_{\mathrm{ij}}$

where $\mu$ is the overall mean, block ${ }_{i}$ and $\varepsilon_{i j}$ are the random effects of the ith block $(i=1,2, \ldots, 5)$ and the residual effect tre represents the fixed effects of the $j$ th treatment $(j=1,2, \ldots, 6)$. All of the random effects were assumed to be mutually independent. The statistical model was fitted using the restricted maximum likelihood (REML) estimation method and SAS/MIXED software (version 9.2).

The distributions of all variables were skewed. Logarithmic transformations were used to normalize the data distribution before statistical analysis. All of the estimates were transformed back to the original scale, except for the standard errors. 


\section{Results and discussion}

\section{Field monitoring of drainage water}

In the drainage water from paddocks constructed using woodchips and amended with $\mathrm{Ca}(\mathrm{OH})_{2}$ or $\mathrm{Fe}\left(\mathrm{SO}_{4}\right)_{3}$, the concentrations of DRP and TP were small ( $\leq 0.01$ and $\leq 0.51 \mathrm{mg} \mathrm{l}^{-1}$, respectively) at the beginning of the study but increased during the 3 years of observation (Fig. 3). The observed DRP and TP values were often lower for woodchips amended with $\mathrm{Fe}_{2}\left(\mathrm{SO}_{4}\right)_{3}$ than those amended with $\mathrm{Ca}(\mathrm{OH})_{2}$. Other studies have reported that Fe-containing materials on the soil surface provided better results than Ca-containing materials (Uusi-Kämppä et al. 2012), whereas Ca-based materials typically work under very alkaline (pH 9-12) conditions (Berné and Richard 1991, Diaz et al. 1994). The other reason for a smaller DRP concentration from the $\mathrm{Fe}_{2}\left(\mathrm{SO}_{4}\right)_{3}$-amended paddock was that 15$\mathrm{cm}$ sand layer under the woodchips, which was not present in the $\mathrm{Ca}(\mathrm{OH})_{2}$-amended paddock (Fig. 2).

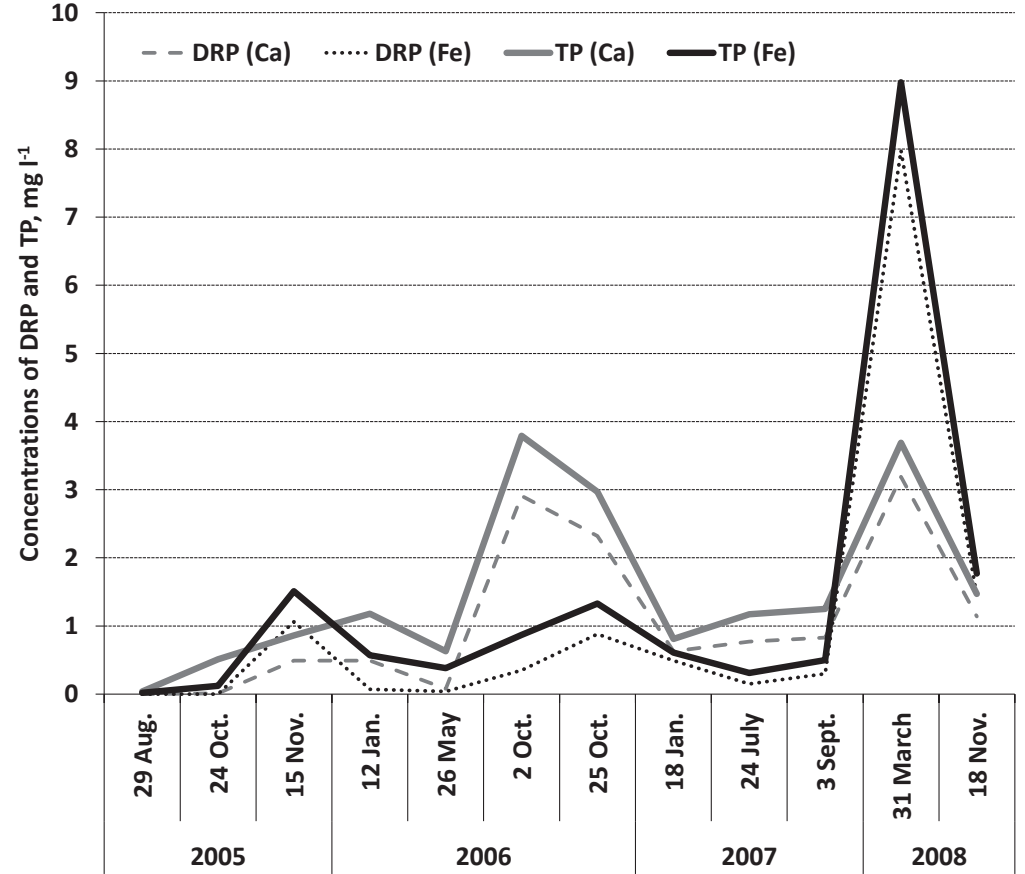

Fig. 3. Concentrations of dissolved reactive phosphorus (DRP) and total phosphorus (TP) in drainage water from the paddock constructed out of woodchips and amended with $\mathrm{Ca}(\mathrm{OH})_{2}$ (slaked lime) or $\mathrm{Fe}_{2}\left(\mathrm{SO}_{4}\right)_{3}$ (Ferix-3) during the field monitoring study.

High DRP concentrations (up to $3 \mathrm{mg}^{-1}$ ) were measured in the drainage water from $\mathrm{Ca}(\mathrm{OH})_{2}$-amended woodchips in October 2006 and March 2008. These values are 2-6-fold higher than the values reported by Jansson et al. (2000) for open ditches adjacent to stable areas. The paddock drainage flow in the present study was not diluted with other runoff water originating from areas outside the paddocks. In Sweden, Parvage et al. (2011) measured 13-fold and 3-fold higher mean concentrations of DRP and TP, respectively, in drainage water from a grazed horse paddock ( 3.75 livestock units ha-1) compared to the water from the adjacent arable land. Peak values were also observed in paddock flow, occasionally exceeding $1.5 \mathrm{mg} \mathrm{I}^{1^{-1}} \mathrm{TP}$ and $1 \mathrm{mg} \mathrm{l}^{-1} \mathrm{DRP}$ in the spring and autumn, but no peaks were observed in the drainage water from arable land.

A high DRP concentration of $8 \mathrm{mg}^{-1}$ was measured in the drainage water from the $\mathrm{Fe}_{2}\left(\mathrm{SO}_{4}\right)_{3}$-amended paddock in March 2008 (Fig. 3). An equally high DRP concentration was measured earlier in percolation water from a forested feedlot for cattle where no P-sorbing materials were used (Uusi-Kämppä 2002). The effectiveness of $\mathrm{Fe}_{2}\left(\mathrm{SO}_{4}\right)_{3}$ in retaining P probably decreased or was depleted after 2 years. The PP concentrations were low $\left(<1 \mathrm{mg} \mathrm{l}^{-1}\right)$, probably due to the ability of the underlying clay soil to prevent particles from entering the drainage water.

The $\mathrm{pH}$ level was slightly higher in the drainage flow from woodchips amended with $\mathrm{Ca}(\mathrm{OH})_{2}$ (mean 7.0) compared to $\mathrm{Fe}_{2}\left(\mathrm{SO}_{4}\right)_{3}$ (mean 6.8), which is an acidic product $(\mathrm{pH}<2)$. In this preliminary study, comparison of the two Psorbing materials was difficult due to the absence of a calibration period and presence of a sand layer in the footing amended with $\mathrm{Fe}_{2}\left(\mathrm{SO}_{4}\right)_{3}$ (Fig. 2). 


\section{Rainfall study 1 and surface runoff}

Extremely high DRP concentrations $\left(45 \mathrm{mg} \mathrm{l}^{-1}\right)$ were measured in runoff when crushed stone was used as the footing material and the dung was not removed immediately from the paddock area (data not shown). Very high DRP concentrations (6-18 $\mathrm{mg} \mathrm{l}^{-1}$ ) were also obtained from sand footings without any P-sorbing material (Fig. 4) compared to the corresponding DRP value of $2.2 \mathrm{mg} \mathrm{l}^{-1}$ for clay footing. Similar DRP concentrations (up to $15.0 \mathrm{mg} \mathrm{l}^{-1}$ ) were measured in the surface runoff from paddocks in the study by Airaksinen et al. (2007). In our study, most of the P was in the form of DRP in the runoff from footings, similar to the studies by Airaksinen et al. (2007) and Närvänen et al. (2008).

In Finland, Jansson et al. (2000) observed 3- to 4-fold higher concentrations of DRP $\left(0.55 \mathrm{mg} \mathrm{l}^{-1}\right)$ and TP (1.28 mg $\mathrm{I}^{-1}$ ) in ditch water adjacent to horse areas compared to the ditches of agricultural fields. However, in the field study by Turtola and Kemppainen (1998), the DRP concentration in runoff peaked at $25 \mathrm{mg} \mathrm{l}^{-1}$ after applying cattle slurry to snow-covered soil. Runoff and DRP concentrations were high in both the water-saturated samples of the present study and the frozen field in Turtola and Kemppainen's (1998) study due to the limited percolation of water into the ground. In the rainfall simulations, the concentrations in runoff may have been higher than in nature due to the rather high rainfall intensity $\left(21 \mathrm{~mm} \mathrm{~h}^{-1}\right)$. Thus, the experiment demonstrates the worst situations during snow melting, when the soil is frozen and runoff at its highest.

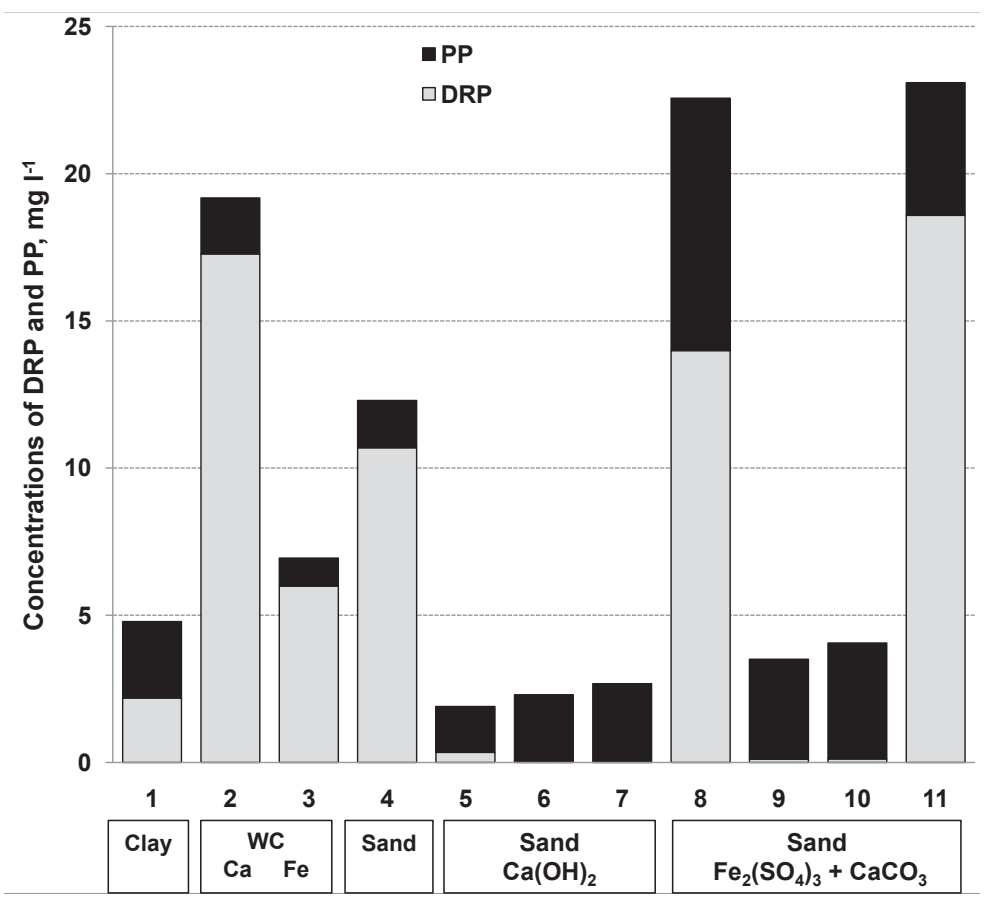

Fig. 4. Concentrations of dissolved reactive phosphorus (DRP) and particulate phosphorus (PP) in surface runoff from footings constructed of clay, woodchips, and sand with P-sorbing materials during rainfall study 1 . The application rates are presented in Table 2.

\section{Performance of P-sorbing materials}

The concentrations of DRP and TP in the runoff were lower for woodchips amended with $\mathrm{Fe}_{2}\left(\mathrm{SO}_{4}\right)_{3}(0.84$ tn ha-1) than for woodchips amended with the same amount of $\mathrm{Ca}(\mathrm{OH})_{2}$ (Fig. 4). Lower concentrations of DRP and TP were also measured in the drainage flow after $\mathrm{Fe}_{2}\left(\mathrm{SO}_{4}\right)_{3}$ application compared to $\mathrm{Ca}(\mathrm{OH})_{2}$ application at the same site in 2006 and 2007. The DRP and TP concentrations were lower overall in the drainage flow than in the surface runoff, probably due to the adsorption of DRP on the sand layer, the P-sorbing materials applied to the woodchips, and the sieving effect of the clay soil. In the top layer sampled for the simulation, the amount of $\mathrm{Ca}(\mathrm{OH})_{2}$ that was applied may have been lower than in the deeper layer, resulting in less efficient retention of DRP from the runoff compared to the runoff from the $\mathrm{Fe}_{2}\left(\mathrm{SO}_{4}\right)_{3}$-amended woodchips. This observation was due to the application of Ca-containing materials to a depth of $10 \mathrm{~cm}$ to protect the horses from eating the chemical compound. In contrast, granular Fe-containing materials were applied on the surface of the woodchip material, from where it was thought to penetrate into deeper layers over time. 
The addition of $2.5 \mathrm{tn} \mathrm{ha-1} \mathrm{Ca}(\mathrm{OH})_{2}$ to the sand surface in the laboratory decreased the DRP and TP concentrations by $97 \%$ and $85 \%$, respectively, compared to the sand without amendments (Fig. 4). The added amounts of Fe $\left(\mathrm{SO}_{4}\right)_{3}$ ( $2 \mathrm{tn} \mathrm{ha}^{-1}$ ) and $\mathrm{CaCO}_{3}$ (6.7 $\mathrm{tn} \mathrm{ha}^{-1}$ ) were not effective at decreasing the concentrations. When the amount of applied Fe was doubled, the decrease in DRP and TP was $99 \%$ and $71 \%$, respectively. On the other hand, the use of $\mathrm{CaCO}_{3}$ alone had no effect on the values (Fig. 4).

\section{Rainfall study 2 and percolation water}

\section{Phosphorus loss}

The general trend was that percolation water from a sand footing had $100 \%, 89 \%$, and $97 \%$ lower concentrations of DRP, PP, and TP compared to a footing made of woodchips ( $p<0.0001$, Table 3 ). No addition of Fe or Ca was needed as the sand itself was very effective at decreasing the DRP, PP, and TP concentrations in the percolation water. The sand used probably included Fe, resulting in the retained DRP being liberated from the horse dung during the rainfall simulations.

One reason for the high $\mathrm{P}$ concentrations in the footings constructed using aspen woodchips was the liberation of DRP into the percolation water from the footing material itself $\left(0.47-0.94 \mathrm{mg} \mathrm{l}^{-1}\right)$ before dung application. High TP concentrations in effluents from hardwood (up to $40 \mathrm{mg} \mathrm{l}^{-1}$ ) were initially observed by Chardon et al. (2011) when nitrate was removed from the drainage water using woodchips. In our study, the high DRP concentration from woodchips was significantly decreased (over 76\%) by the addition of $\mathrm{Ca}(\mathrm{OH})_{2}$ or Fe-gypsum to the footing material (Table 3). However, $\mathrm{Ca}(\mathrm{OH})_{2}$ was not as effective as Fe-gypsum in reducing the TP concentration $(46 \%, p=0.012$ and $67 \%, p<0.001$, respectively). The DRP concentrations in the water from woodchips amended with $\mathrm{Ca}$ - and Febased materials were the same as in the field monitoring study (see Fig. 3).

Altogether, four single samples (woodchips, woodchips with $\mathrm{Ca}(\mathrm{OH})_{2}$, woodchips with Fe-gypsum, and sand) were amended with horse dung ( $30 \mathrm{~g}$, containing $17 \mathrm{mg} \mathrm{TP}$ ) and irrigated (10 $\mathrm{mm} \mathrm{h}^{-1}, 3 \mathrm{~h}$ ) a third time. The resulting DRP concentrations in the percolation water were $11.30,8.68,5.80$, and $0.04 \mathrm{mg} \mathrm{l}^{-1}$, respectively. This experiment showed that the effect of P-sorbing materials may decrease over time and that P loss can increase again in paddock runoff. However, the DRP concentration from the sand footing was still low. The footing was loaded according to a horse density of 1 horse ha- ${ }^{-1}$, whereas the typical density in Finnish paddocks is up to 5.3 horses ha- $^{-1}$ (Pikkarainen 2005). In practise, the paddocks are loaded for several years, whereas in our study the annual load of a single horse was given once. Thus, paddocks may be more heavily loaded than in this study.

The highest DRP content $\left(2.7 \mathrm{mg}\right.$, equivalent to $\left.1.5 \mathrm{~kg} \mathrm{ha}^{-1}\right)$ was from the paddock footing constructed out of woodchips, partly due to the rather high DRP content ( $1.0 \mathrm{mg}$ in 0-sample) of the woodchip material itself. Overall, up to one-fifth of the TP input leached through the footing constructed of woodchips without any P-sorbing material. The addition of $\mathrm{Ca}(\mathrm{OH})_{2}$ and Fe-gypsum decreased the DRP load by $75 \%$ and $83 \%$, respectively (Table 3 ). The TP content $\left(3.6 \mathrm{mg}\right.$ ) was decreased by $68 \%$ by the addition of Fe-gypsum (Table 3), whereas the addition of $\mathrm{Ca}(\mathrm{OH})_{2}$ did not decrease the load significantly.

The DRP load into the percolation water from the sand footing was negligible $(<0.001 \mathrm{mg}$, Table 3$)$. However, the water volume was $25 \%$ less from the sand footings than footings constructed out of woodchips due to high permeability of the woodchip material. The average percolation flow was $90 \mathrm{~mm}$ and up to $120 \mathrm{~mm}$ for sand and woodchips, respectively, when total precipitation was approximately $110 \mathrm{~mm}$. Although the sand footing efficiently retained DRP, its infiltration capacity may decrease over time, increasing the risk of surface runoff. The TP content of $0.1 \mathrm{mg}$ in the percolation water from the sand footing was decreased by $78 \%$ and $60 \%$ by applying Fe-gypsum and $\mathrm{Fe}_{2}\left(\mathrm{SO}_{4}\right)_{3}$, respectively. In particular, the $10-\mathrm{cm}$ sand layer below the layer of woodchips in the monitoring study might also be a significant reason for the lower $\mathrm{P}$ concentration in the drainage water from the $\mathrm{Fe}_{2}\left(\mathrm{SO}_{4}\right)_{3}$-amended paddock compared to the $\mathrm{Ca}(\mathrm{OH})_{2}$-amended paddock. 


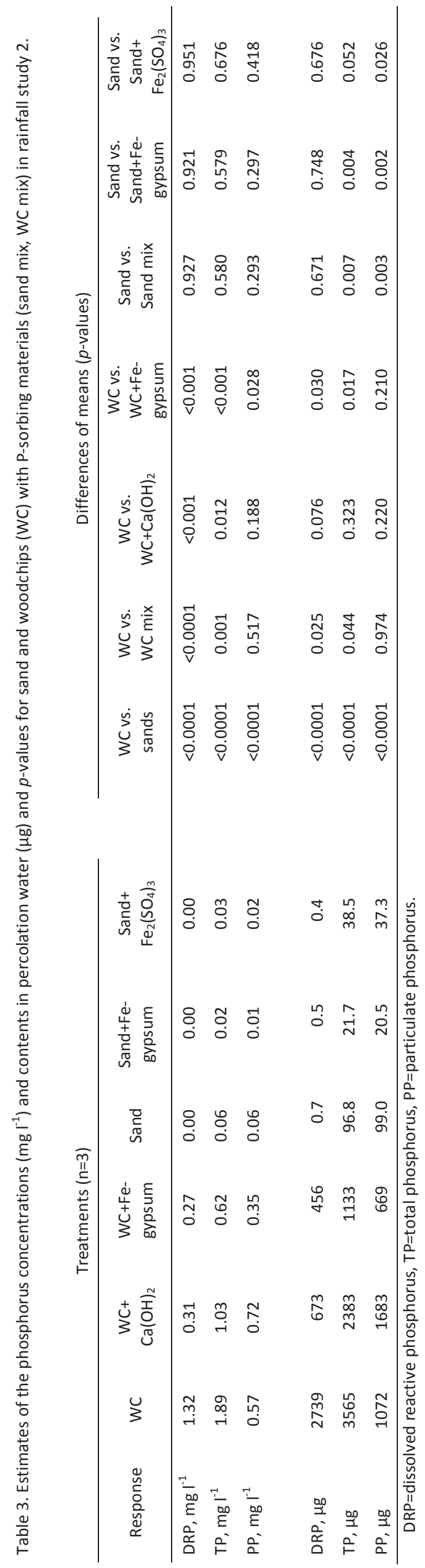




\section{Levels of bacteria in faeces and water}

In addition to $\mathrm{P}$, the levels of faecal bacteria were studied in faeces sampled from the horse's rectum, dung on the surface of the paddock footings, and water samples. The number of presumptive $E$. coli in fresh faeces collected directly from 10 horses in the Ypäjä area was between $6.6 \times 10^{4}$ and $4.6 \times 10^{7} \mathrm{~g}^{-1}$ (dry weight). Similarly, in dry manure collected from a paddock for the rainfall simulations, the geometric means for the number of presumptive E. coli were $7.0 \times 10^{4}$ and $1.7 \times 10^{4} \mathrm{cfu} \mathrm{g}^{-1}$ for the first and second dung samples, respectively (Table 4). Weaver et al. (2005) counted $E$. coli and faecal streptococcus in fresh manure from horses in a pasture and reported similar numbers as we found in the dung used in the rainfall simulation.

Table 4. The mean numbers of presumptive E.coli, other coliforms, Faecal coliforms, Faecal streptococcus, and sulfitereducing clostridia in the dung of rainfall study 2 .

\begin{tabular}{llllll}
\hline $\begin{array}{l}\text { Dung } \\
\text { sample }\end{array}$ & $\begin{array}{l}\text { E.coli } \\
\text { salyer }\end{array}$ & $\begin{array}{l}\text { Other } \\
\text { coliforms }\end{array}$ & $\begin{array}{l}\text { Faecal } \\
\text { coliforms }\end{array}$ & $\begin{array}{l}\text { Faecal } \\
\text { streptococcus }\end{array}$ & $\begin{array}{l}\text { Sulfite-reducing } \\
\text { clostridia }\end{array}$ \\
\hline & $7.0 \times 10^{4}$ & $1.6 \times 10^{5}$ & $9.4 \times 10^{4}$ & $1.5 \times 10^{7}$ & $1.6 \times 10^{3}$ \\
2 & $1.7 \times 10^{4}$ & $6.2 \times 10^{4}$ & $2.4 \times 10^{4}$ & $2.1 \times 10^{7}$ & $2.7 \times 10^{2}$ \\
\hline
\end{tabular}

Field monitoring of drainage water

In the drainage water from the paddock footing made of woodchips, the levels of indicator bacteria decreased over time (Table 5), whereas the concentrations of $P$ fractions increased (Fig. 3). The levels of faecal coliforms $\left[2.4 \times 10^{2}-6.7 \times 10^{5} \mathrm{cfu}(100 \mathrm{ml})^{-1}\right]$ were of a similar order of magnitude as those measured for forested feedlots for suckler cows in eastern Finland (Uusi-Kämppä et al. 2001). In the present study, the number of presumptive E. coli and faecal streptococcus was less in runoff from the paddock where $\mathrm{Fe}_{2}\left(\mathrm{SO}_{4}\right)_{3}$ was used compared to the paddock amended with $\mathrm{Ca}(\mathrm{OH})_{2}$. The sand layer in the Fe-amended footing may also have decreased bacterial levels in the water. In all three studies, the levels of sulfite-reducing clostridia were below the detection limit of the method used.

Table 5. Presumptive $E$. coli, other coliforms, faecal coliforms, and faecal streptococcus in drainage water from the paddock constructed out of woodchips and amended with $\mathrm{Ca}(\mathrm{OH})_{2}$ or $\mathrm{Fe}_{2}\left(\mathrm{SO}_{4}\right)_{3}$ (Ferix-3) in the field monitoring study.

\begin{tabular}{|c|c|c|c|c|c|c|c|c|}
\hline \multirow[t]{3}{*}{ Time period } & \multicolumn{2}{|c|}{ E. coli } & \multicolumn{2}{|c|}{ Other coliforms } & \multicolumn{2}{|c|}{ Faecal coliforms } & \multicolumn{2}{|c|}{ Faecal streptococcus } \\
\hline & \multicolumn{8}{|c|}{ cfu $(100 \mathrm{ml})^{-1}$} \\
\hline & $\mathrm{Ca}(\mathrm{OH})_{2}$ & $\mathrm{Fe}_{2}\left(\mathrm{SO}_{4}\right)_{3}$ & $\mathrm{Ca}(\mathrm{OH})_{2}$ & $\mathrm{Fe}_{2}\left(\mathrm{SO}_{4}\right)_{3}$ & $\mathrm{Ca}(\mathrm{OH})_{2}$ & $\mathrm{Fe}_{2}\left(\mathrm{SO}_{4}\right)_{3}$ & $\mathrm{Ca}(\mathrm{OH})_{2}$ & $\mathrm{Fe}_{2}\left(\mathrm{SO}_{4}\right)_{3}$ \\
\hline Nov. 2005 & n.a. & n.a. & n.a. & n.a. & $4.1 \times 10^{5}$ & $6.7 \times 10^{5}$ & $1.5 \times 10^{5}$ & $1.0 \times 10^{5}$ \\
\hline Oct. 2006 & $2.7 \times 10^{4}$ & $5.8 \times 10^{3}$ & $4.9 \times 10^{4}$ & $3.5 \times 10^{4}$ & n.a. & n.a. & $3.0 \times 10^{4}$ & $1.7 \times 10^{4}$ \\
\hline Sept. 2007 & $3.5 \times 10^{4}$ & $4.5 \times 10^{2}$ & $6.2 \times 10^{4}$ & $1.8 \times 10^{4}$ & n.a. & n.a. & $3.5 \times 10^{4}$ & $4.5 \times 10^{2}$ \\
\hline Nov. 2008 & $3.0 \times 10^{1}$ & $1.5 \times 10^{1}$ & $4.7 \times 10^{2}$ & $1.5 \times 10^{3}$ & $2.4 \times 10^{2}$ & $1.5 \times 10^{3}$ & $1.5 \times 10^{3}$ & $5.3 \times 10^{2}$ \\
\hline
\end{tabular}

Rainfall study 1 and surface runoff

High numbers of presumptive $E$. coli $\left[1.7 \times 10^{4}-5.5 \times 10^{5} \mathrm{cfu}(100 \mathrm{ml})^{-1}\right]$ were measured in the runoff from all footing materials collected from the horse paddocks (Fig. 5). The numbers of presumptive $E$. coli were also high in the runoff from sand footing, but the addition of $10 \mathrm{tn} \mathrm{ha}^{-1}$ of $\mathrm{Ca}(\mathrm{OH})_{2}$ to the sand reduced the numbers to below the detection limit. The $\mathrm{pH}$ value of the runoff increased up to 11.7-12.5, killing micro-organisms. Swedish experiments showed that $\mathrm{Ca}(\mathrm{OH})_{2}$ is effective in inactivating Salmonella typhimurium if a sufficient increase in $\mathrm{pH}$ is achieved $(\mathrm{pH}>11)$ and maintained for several days (Nyberg et al. 2011). 


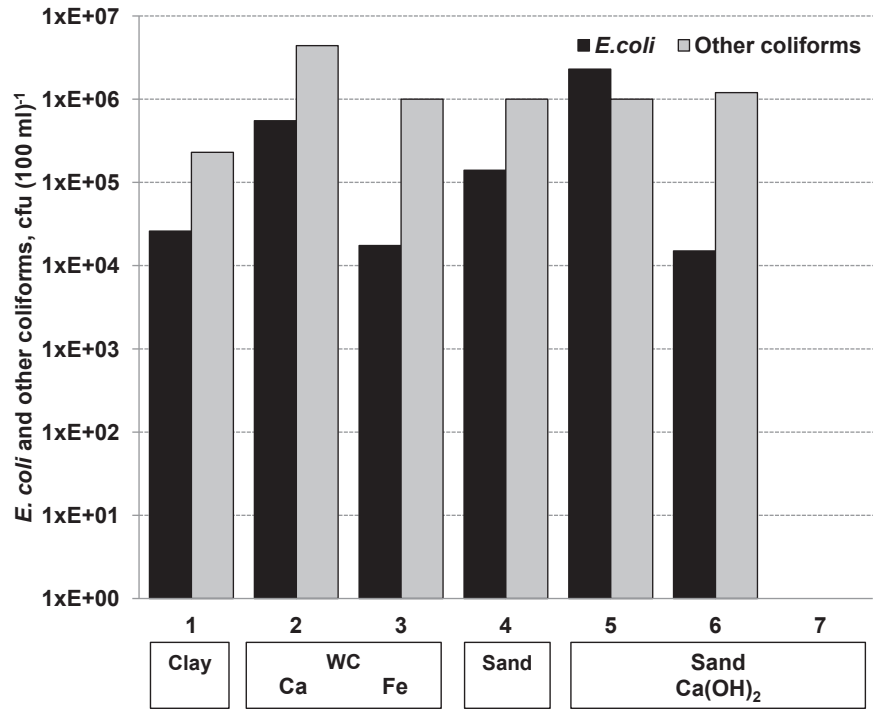

Fig. 5. Numbers of presumptive E. coli and other coliforms in surface runoff from footings constructed of clay, woodchips, and sand with P-sorbing materials during rainfall study 1 . The application rates are presented in Table 2. Note that the number of bacteria is below the detection limit in the case of sand amended with $10 \mathrm{tn} \mathrm{ha}^{-1}$ $\mathrm{Ca}(\mathrm{OH})_{2}$.

\section{Rainfall study 2 and percolation water}

Fewer faecal coliforms were present in the percolation water from the sand footing than from the footing constructed out of woodchips due to the better retention capacity of the sand (Fig. 6). The pore space in the sand footing was smaller than in the footing constructed of woodchips; therefore, the sand probably prevented the transport of microbes into the percolation water better than the woodchips. The levels of faecal coliforms and $E$. coli in the water were reduced by the application of Fe-gypsum to the sand footing. The addition of $\mathrm{Fe}_{2}\left(\mathrm{SO}_{4}\right)_{3}$ to the sand completely removed coliforms and faecal streptococcus from the water due to the decrease in $\mathrm{pH}(\mathrm{pH}$ 4.8-5.1). Although the addition of $\mathrm{Ca}(\mathrm{OH})_{2}$ and Fe-gypsum decreased the numbers of faecal coliforms, rather high levels $\left[3.3 \times 10^{2}\right.$ to $\left.2.5 \times 10^{4} \mathrm{cfu}(100 \mathrm{ml})^{-1}\right]$ were measured in the percolation water from footings constructed out of woodchips. The reason for the poor reduction of $E$. coli, faecal coliforms, and faecal streptococcus by $\mathrm{Ca}(\mathrm{OH})_{2}$, was that the amount applied was not sufficient to increase the $\mathrm{pH}$ above 11; the $\mathrm{pH}$ remained between 7.6 and 9.0 (data not shown). The Fe-gypsum had no effect on the $\mathrm{pH}$

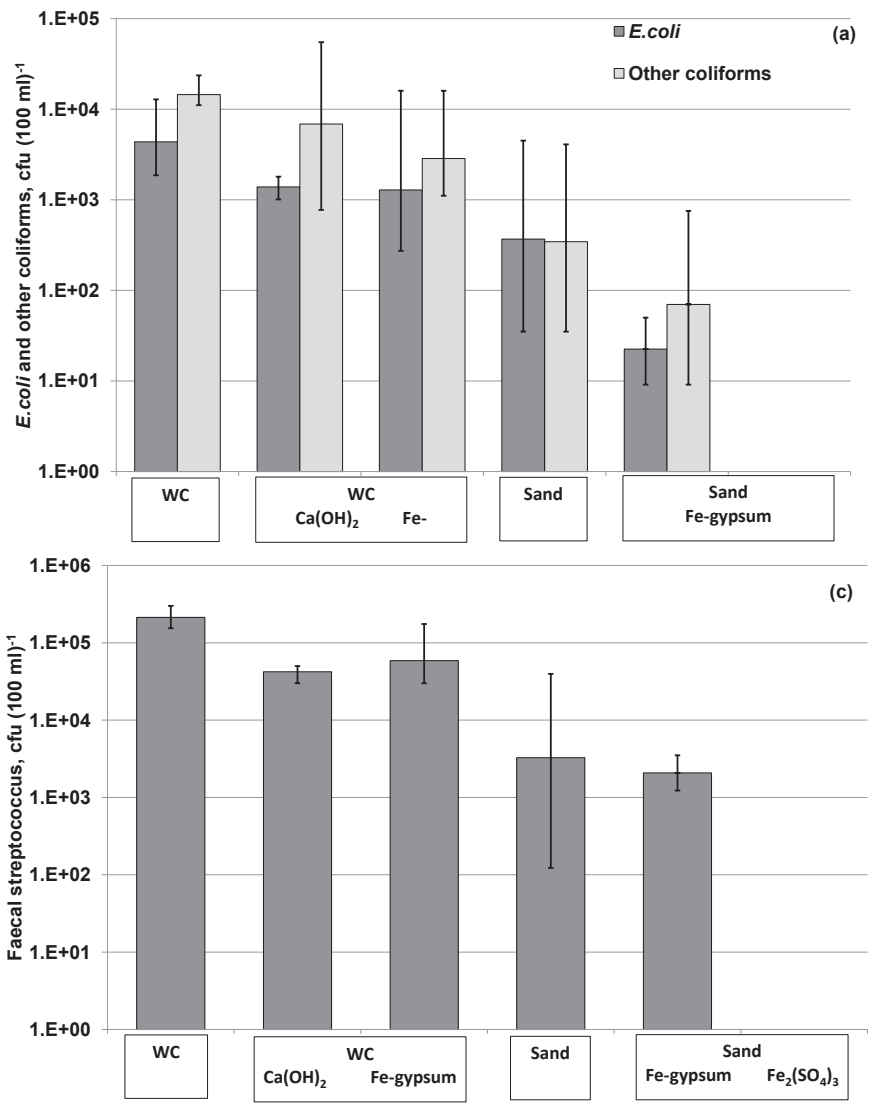

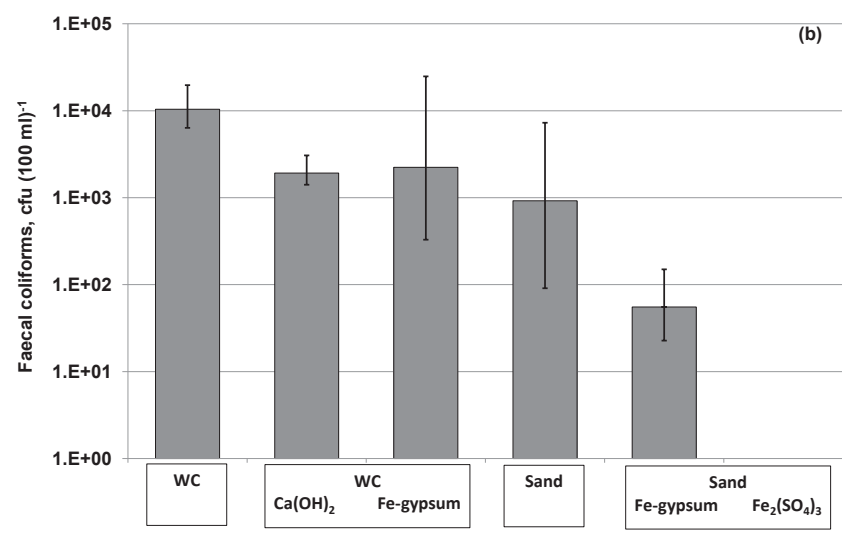

Fig. 6. Numbers of presumptive E. coli, other coliforms (a), faecal coliforms (b), and faecal streptococcus (c) in percolation water from footings constructed of woodchips (WC) or sand and amended with $\mathrm{Ca}$ - or Fe-containing materials during rainfall study 2. Data are the geometric mean of three replicates. Error bars indicate maximum and minimum values. Note that the number of bacteria is below the detection limit in the case of sand amended with $\mathrm{Fe}_{2}\left(\mathrm{SO}_{4}\right)_{3}$. 


\section{Conclusions}

High concentrations of DRP and TP, as well as high levels of indicator bacteria, were observed in drainage water and runoff from horse paddocks. According to the current guidelines, horse paddocks must be established in a way that eliminates the risk for groundwater pollution and minimizes the risk of surface water pollution (Finnish Ministry of the Environment 2003). The distance from a paddock to a main ditch should be at least $20 \mathrm{~m}$, and to a brook or watershed at least $100 \mathrm{~m}$. Droppings must be removed from the surface of a paddock frequently (Finnish Ministry of the Environment 2003). Not all Finnish paddocks are managed according to these guidelines: some are situated too near to waters, some have no drainage system, some were improperly established, and in some droppings are not removed regularly. However, our results show that a very high risk exists for the loss of both $\mathrm{P}$ and faecal micro-organisms into runoff from the paddocks to water, but the risk can be reduced by choosing good footing materials and adding P-sorbing material.

In the present study, sand footing retained DRP, TP, and faecal coliforms better than woodchips. The DRP and TP concentrations and number of bacteria were lower in the percolation water than in the surface runoff water, as the footing materials retained $P$ and filtered out coliforms. In practice, the surface should have a good infiltration capacity, and the drainage system should function well to prevent surface runoff from the paddocks. The paddocks must be built in a way that the soil is first drained, and then the footing material added (Jansson and Särkijärvi 2010).

Application of Fe-containing materials to the footing decreased DRP concentrations, as well as the number of faecal coliforms, in the percolation water. However, P-sorbing materials may not work efficiently in winter when the paddock surface is frozen. More information is needed about the best amendments and suitable amounts for different conditions. Problems were not detected in the mouths of horses, though 0.84 tn ha-1 of slaked lime or $\mathrm{Fe}_{2}\left(\mathrm{SO}_{4}\right)_{3}$ was added to footings constructed out of woodchips. Because the higher rate of P-sorbing materials (as applied in the rainfall simulation studies) was not tested in a real paddock, we cannot guarantee a lack of health risks to horses. In light of the results obtained in the present study, further studies are required to test P-sorbing materials, including the effects of the materials on horse health.

\section{Acknowledgements}

The study was partially funded by MTT. The authors are especially grateful to EquineLife project for providing the prototype paddocks constructed of woodchips for monitoring drainage water. Taisto Sirén and Ari Seppänen are also acknowledged for the indoor rainfall simulations.

\section{References}

Agyin-Birikorang, S., O'Connor, G.A., Jacobs, L.W., Makris, K.C. \& Brinton, S.R. 2007. Long-term phosphorus immobilization by a drinking water treatment residual. Journal of Environmental Quality 36: 316-323.

Airaksinen, S., Heiskanen, M.-L. \& Heinonen-Tanski, H. 2007. Contamination of surface run-off water and soil in two horse paddocks. Bioresource Technology 98: 1762-1766.

Berné, F. \& Richard, Y. 1991. Water Treatment Handbook. Chapter 3. Basic physical-chemical processes in water treatment. Chemical precipitation. Vol. 1. $6^{\text {th }}$ ed. Degrémont Water and Environment. Paris: Lavoisier Publishing. p. 146-157.

Chardon, W.J., Pleijter, M. \& Koopmans, G.F. 2011. Removal of nitrate from drainage water using wood chips. In: Realistic expectations for improving European waters. Final conference of COST Action 869. Mitigation Options for Nutrient Reduction in Surface Water and Groundwaters. Keszthely, Hungary, 12-14 October 2011. Abstracts. p. 18.

Correll, D.L. 1998. The role of phosphorus in the eutrophication of receiving waters: a review. Journal of Environmental Quality 27: 261-266.

Diaz. O.A., Reddy, K.R. \& Moore Jr., P.A. 1994. Solubility of inorganic phosphorus in stream water as influenced by pH and calcium concentration. Water Research. 28: 1755-1763.

Finnish Ministry of the Environment. Hevostallien ympäristönsuojeluohje 4.11.2003. Ympäristöministeriön moniste 121. (In Finnish). Helsinki 2003.

Jansson, H., Mäntylahti, V., Närvänen, A. \& Uusitalo, R. 2000. Phosphorus content of ditch sediments as indicator of critical source areas. Research Note. Agricultural and Food Science in Finland 9: 217-221.

Jansson, H. \& Särkijärvi, S. 2010. Talliympäristöopas. Toinen painos. (In Finnish). Ypäjä: MTT/Hevostutkimus. 49 p.

Kynkäänniemi, P., Johannesson, K., Tonderski, K. \& Ulén. B. 2010. Constructed wetland to mitigate P losses from hotspots in agricultural areas. In: Turtola, E., Ekholm, P. \& Chardon, W. (eds.). Novel Methods for Reducing Agricultural Nutrient Loading and Eutrophication: Meeting of Cost 869, 14-16 June, Jokioinen, Finland. MTT Science 10. 22 p.

LABM. HAL008. Harlequin ${ }^{\text {TM }}$. E.coli /Coliform Medium http://www.labm.com/data/Product_Downloads/HAL008\%20technical\%20 flyer.pdf 
Murphy, J. \& Riley, P. 1962. A modified single solution method for the determination of phosphate in natural waters. Analytica Chimica Acta 27: 31-36.

Närvänen, A., Jansson, H., Uusi-Kämppä, J., Jansson, H. \& Perälä, P. 2008. Phosphorus load from equine critical source areas and its reduction using ferric sulphate. Boreal Environment Research 13: 265-274.

Nyberg, K., Vinnerås, B. \& Albihn, A. 2011. Managing pathogen contamined horse paddocks with hydrated lime as hygienic treatment. In: NJF Seminar 437, Housing and Management of Horses in Nordic and Baltic Climate. Reykjavik, Iceland, 6-7 June 2011. NJF Report 7(2): 21.

O'Connor, G.A., Brinton, S. \& Silveira M.L. 2005. Evaluation and selection of soil amendments for field testing to reduce P losses. Soil and Crop Science Society of Florida, Proceedings 64: 22-34.

Parvage, M.M., Kirchmann, H., Kynkäänniemi, P. \& Ulén, B. 2011. Impact of horse grazing and feeding on phosphorus concentrations in soil and drainage water. Soil Use and Management 27: 367-375.

Penn, C.J. \& Bryant, R.B. 2006. Application of phosphorus sorbing materials to streamsite cattle loafing areas. Journal of Soil and Water Conservation 61: 303-310.

Pikkarainen, M. 2005. Hevosten hyvinvointi ja lajinmukainen käyttäytyminen sekä niiden toteuttaminen suomalaisilla talleilla. (In Finnish). Opinnäytetyö, Maaseutuelinkeinojen koulutusohjelma, Hämeen ammattikorkeakoulu, Mustiala.

SFS 3014 1984. Enumeration of faecal streptococci in water with colony counting methods. Helsinki: Finnish Standards Association. 7 p.

SFS 3025 1986. Determination of phosphate in water. Helsinki: Finnish Standards Association. 10 p.

SFS 3026 1986. Determination of total phosphorus in water. Digestion with peroxodisulfate. Helsinki: Finnish Standards Association. $11 \mathrm{p}$.

SFS 4088 1988. Membrane filter technique for the enumeration of thermotolerant (fecal) coliform bacteria in water. Helsinki: Finnish Standards Association. $4 \mathrm{p}$.

SFS-EN-26461-2 1993. Water quality. Detection and enumeration of the spores of sulfite-reducing anaerobes (clostridia). Part 2: Method by membrane filtration. Helsinki: Finnish Standards Association. 7 p.

Sharpley, A.N., Tillman, R.W. \& Syers, J.K. 1977. Use of laboratory extraction data to predict losses of dissolved inorganic phosphate in surface runoff and tile drainage. Journal of Environmental Quality 6: 33-36.

Sinton, L.W., Finlay, R.K. \& Hannah, D.J. 1998. Distinguishing human from animal faecal contamination in water: a review. New Zealand Journal of Marine and Freshwater Research 32: 323-348.

Stephenson, G., Hannaway, D., Blickle, A., Brewer, L., Brewer, L.J., Chaney, M. \& Livesay, M. 2003. Managing Small-Acreage Horse Farms. For Green Pastures, Clean Waters, and Healthy Horses. Oregon State University, Extension Service. EC 1558, May 2003. 24 p.

Sullivan, K. 2010. Literature review: Equine facility runoff.Cited 20 August 2012. Available on the Internet: http://water.rutgers. edu/Research/equine_runoff_lit_review_042910.pdf

Suomen Hippos ry, Fintoto Oy \& Suomen Hevosurheilulehti Oy. 2012. Suomen Hippos -konsernin vuosikertomus 2011. (In Finnish). Cited 20 August 2012. Available on the Internet: http://www.hippos.fi/files/4004/hippos_vk_2011_lopullinen.pdf.

Turtola, E. 1996. Peroxodisulphate digestion and filtration as sources of inaccurancy in determinations of total phosphorus and dissolved orthophosphate phosphorus in water samples containing suspended soil particles. Boreal Environment Research 1: 17-26.

Turtola, E. \& Kemppainen, E. 1998. Nitrogen and phosphorus losses in surface runoff and drainage water after application of slurry and mineral fertilizer to perennial grass ley. Agricultural and Food Science in Finland 7: 569-581.

Uusi-Kämppä, J., Grék, K. \& Jansson, H. 2001. Ulkotarhojen vesistökuormitus. In: Manninen, M. (ed.). Hyvinvoivat naudat puhtaassa ympäristössä. Loppuraportti. (In Finnish). Jokioinen: MTT. p. 67-79.

Uusi-Kämppä, J. 2002. Nitrogen and phosphorus losses from a feedlot for suckler cows. Agricultural and Food Science in Finland. 11: 355-369.

Uusi-Kämppä, J., Turtola, E., Närvänen, A., Jauhiainen, L. \& Uusitalo, R. 2012. Phosphorus mitigation during springtime runoff by amendments applied to grassed soil. Journal of Environmental Quality 41: 420-426. doi:10.2134/jeq2010.0441

Uusitalo, R. \& Aura, E. 2005. A rainfall simulation study on the relationships between soil test P versus dissolved and potentially bioavailable particulate phosphorus forms in runoff. Agricultural and Food Science 14: 335-345.

Weaver, R.W., Entry, J.A., Graves, A. 2005. Numbers of fecal streptococci and Escherichia coli in fresh and dry cattle, horse, and sheep manure. Canadian Journal of Microbiology 51: 847-851. 